\title{
The Origins of Supranational State Aid Legislations: What Policymakers Must Know and Adhere to. The Case of Estonia
}

\section{Evelin Pärn-Lee}

TalTech Law School, Tallinn University of Technology Akadeemia tee 3 , Tallinn 12618, Estonia Email: Evelin.Parn-Lee@taltech.ee

\begin{abstract}
As an independent country, Estonia can decide on how to promote its economy through state intervention, at least in theory. At the same time, Estonia has been a WTO member since 1999 and an EU Member State since 2004 and must adhere to these rules. Both regimes limit a Member State's ability to interfere in the economy, setting forth rules on when a state can interfere with consequences if the rules are not met. But these rules differ, and the same situation can have a different result depending on the rules applied. Also, both sets of rules limit the competence of a member country to interfere in economy differently, for example, the WTO applies a rather lenient ex post control while in the EU a strict ex ante control by the Commission is used. Also the consequences for failing to adhere are different. Although one of the smallest EU Member States and represented by the Commission in WTO roundtables, it is still relevant for Estonia to have a position on globally applied state interference measures, and present and protect its views, if needed. To successfully promote its economy nationally and in the EU, Estonian policymakers, like those of any other country in the same position, must know not only the applicable state interference rules but also the underlying principles thereof. The article will provide a historical overview of the framework of the supranational state aid regimes of the WTO and the EU, as well as the domestic rules of Estonia. It is aimed at reflecting the principles behind the state aid rules that the domestic policymakers must consider when designing national state interference measures. The author applies classical research
\end{abstract}


methods, namely, reading and interpretation of texts, but also comparing the WTO, EU and Estonian laws on state subsidies.

\author{
Keywords: competition law, Estonia, EU, incentive effect, \\ Innovation, market failure, $R \& D$, State aid, WTO
}

\title{
1. Introduction
}

Subsidies ${ }^{1}$ or State aid ${ }^{2}$ are no modern times features and were common for military and political purposes already in Rome Empire (Gordon, 1949; Brogan, 1936; Boundanella \& Musa, 1979). Subsides, as an economic intervention, are reported to have started with mercantilism, ${ }^{3}$ where the common policies advanced ${ }^{4}$ involved protection of domestic industry, promoting exports and gaining a positive balance of trade (López, 2015).

In the 19th century, the state acted as an agent for industrialization and public resources were employed for industrialization and large infrastructure projects (López, 2015). The 20th century introduced protectionism along with subsidies as a measure for income redistribution and balancing externalities (Hoekman \& Kostecki, 2006). Post-Second World War, leading states started to look for options to limit protectionism and remove relevant obstacles in

$1 \quad$ The term used in the WTO regime. According to Alan O. Sykes, although term 'subsidy' is familiar in economics, it is rarely defined precisely (Sykes, 2003, p. 2), and rightly so, as there is a risk of oversimplifying the concept or making it too complicated. Often it is used synonymously with a government transfer of money to a private person engaged in an economic activity. On the other hand, the term 'subsidy' is referred to a situation where goods or services are offered to an undertaking below market price, or vice versa, a company offering goods or services is paid over the normal market price. Or, further, when a government applies policies that favorably affect the competitive position of a company, it is also called subsidy, whereas by no means all such measures cannot be subsidies in any meaningful sense. Sykes claims that a "subsidy' arises anytime a government program benefits private actors ignores the other side of the ledger-the numerous government programs that impose costs on those same actors" (Sykes, 2003, p. 3). Therefore, he proposes to conceptualize a 'subsidy' in simple economic models and to identify a subsidy in practice (Sykes, 2003, p. 3). Based on this approach, even if a government program on the one hand seems as providing benefits to an industry, such favoring may in fact offset other tax and regulatory burdens that disadvantage the industry. Also, he proposes that any administrable rule for deciding whether a particular government program is a subsidy or not will no doubt result in serious errors of overinclusion and underinclusion. (Sykes, 2003, p. 6)

2 The term used in EU legislation, whereas the term 'State aid' is considered to be broader than the term 'subsidy' used in the WTO regime.

3 Particularly with the French mercantilist Jean-Baptist Colbert.

4 Adam Smith named economic measures in the form of state interventions employed by states a 'mercantilism system'. 
order to enable international trade. This eventually led to the establishment of the World Trade Organization (WTO), together with its supranational subsidies control, the aim of which was to put an end to controlling the subsidies and other interference measures of economy at the domestic level, if at all.

Subsidies do not necessarily mean general harm to economic welfare, or at least they are not considered by the economic theory harmful per se. Even though economists agree that the subsidy regime likely distorts resource allocation and harms competition, both from the perceptive of unsubsidized competitors as well as the taxpayers, subsidies seldom harm consumers directly. On the contrary, the effects of subsidies on consumer welfare, at least good subsidies, are usually positive. For example, a subsidy in public transportation, due to which the consumers benefit by enjoying lower prices, is considered a good subsidy. Export subsidy, however, is considered a bad subsidy, since it harms both the international trade as well as domestic consumers, because export subsidy tends to increase the local price level (Hoekman \& Kostecki, 2006). But even export subsidy, although prohibited per se under the WTO and EU rules, is from an economic point of view not entirely a bad subsidy, as in the case of perfect competition export subsidies granted to national undertakings benefit foreign consumers.

\section{The origins of supranational subsides regime and policy: from the early days to the WTO rules}

Rules on subsidies in the General Agreement on Tariff and Trade (GATT) were initially meant as a complementary measure to custom duties. It was expected that liberalization of trade through decrease of tariff customs will offset domestic support (Matsushita et al., 2006) and, in the 1954-1955 review session, the GATT Article XVI ${ }^{5}$ was amended with Clause 2 providing rules

\footnotetext{
Article XVI(1) of the GATT: "1. If any contracting party grants or maintains any subsidy, including any form of income or price support, which operates directly or indirectly to increase exports of any product from, or to reduce imports of any product into, its territory, it shall notify the CONTRACTING PARTIES in writing of the extent and nature of the subsidization, of the estimated effect of the subsidization on the quantity of the affected product or products imported into or exported from its territory and of the circumstances making the subsidization necessary. In any case in which it is determined that serious prejudice to the interests of any other contracting party is caused or threatened by any such subsidization, the contracting party granting the subsidy shall, upon request, discuss with the other contracting party or parties concerned, or with the CONTRACTING PARTIES, the possibility of limiting the subsidization."
} 
on export subsidies ${ }^{6}$ in general as well as to primary products. ${ }^{7}$ These rules were meant to deter the member countries from applying export subsidies in a way that resulted in export prices being lower than the prices of comparable products on the domestic market. Yet, no definition for the term 'subsidy' was proposed (Krämer \& Krajewski, 2011; Matsushita et al., 2006). In principle, the GATT includes a two-fold approach: on the one hand, prohibiting granting and maintaining certain subsidies and, on the other hand, enabling a GATT member state to impose countervailing duties on products which have been subject to subsidies in their domestic countries (Art. VI(3)), and the approach is valid until today. Also, exempted from general subsidies prohibition are subsidies exclusively for domestic producers (Art. III(3)b); thus, supporting domestic trade is not contrary to the GATT's terms.

The Tokyo Round in the 1960s and 1970s dealt, to a large extent, with lowering tariffs and non-tariff barriers, but additionally, the need of greater disciplines for subsidies in general was raised by the US (Krämer \& Krajewski, 2011). This resulted in the conclusion of the Agreement on Interpretation and Application of Articles VI, XVI and XXIII of the General Agreement on Tariffs and Trade (the so-called Subsidies Code), which upholds the twotrack approach of substantive law and procedural rules of countervailing duties and subsidies; however, it also introduces rules according to which countervailing duty ${ }^{8}$ may only be imposed if a formal investigation has been initiated on the matter (Art. 2(1)) and there is sufficient evidence of (i) existence of subsidy, (ii) injury, and (iii) a causal link between the subsidy and injury (Art. 2(1)). With regard to subsidies, the Subsidies Code retained the current approach that member states are prohibited from granting export

${ }_{6} \quad$ The contracting parties recognize that the granting by a contracting party of a subsidy on the export of any product may have harmful effects for other contracting parties, both importing and exporting, may cause undue disturbance to their normal commercial interests, and may hinder the achievement of the objectives of this Agreement. [...] Accordingly, contracting parties should seek to avoid the use of subsidies on the export of primary products. If, however, a contracting party grants directly or indirectly any form of subsidy which operates to increase the export of any primary product from its territory, such subsidy shall not be applied in a manner which results in that contracting party having more than an equitable share of world export trade in that product, account being taken of the shares of the contracting parties in such trade in the product during a previous representative period, and any special factors which may have affected or may be affecting such trade in the product.

7 For the purposes of Section B, a 'primary product' is understood to be any product of farming, forest or fishery, or any mineral, in its natural form or which has undergone such processing as is customarily required to prepare it for marketing in substantial volume in international trade.

8 According to footnote no. 4 of the Subsidies Code, the term 'countervailing duty' means "a special duty levied for the purpose of off-setting any bounty or subsidy bestowed directly or indirectly upon the manufacture, production or export of any merchandise, as provided for in Article VI (3) of GATT". 
subsidies on products other than certain primary products (Art. 9). Most interestingly, the Subsidies Code provides that subsidies, other than export subsidies, are widely used as important instruments for the promotion of social and economic policy objectives, whereas the Subsidies Code does not intend to restrict the right of signatories to use such subsidies to achieve these and other important policy objectives ${ }^{9}$ which they consider desirable (Art. 11(1)). It is, however, stated that some subsidies might adversely affect the conditions of normal competition, thus signatory countries are requested, when drawing up policies and practices, to weight such effects including with regard to world trade and, in case of possible adverse effects on trade, avoid granting such subsidies (Art. 11(2)).

According to literature, the EU considered the Subsidies Code of having little success, as it did not reduce subsidies granted or countervailing duties applied by the US. Mostly because the Uruguay Round from 1986 to 1993 also dealt with the control of subsidies and countervailing duties and resulted in the next international agreement called the Agreement on Subsidies and Countervailing Measures (SCM). The SCM introduced the definition of the term 'subsidy' along with the traffic light approach on prohibited, actionable, and non-actionable subsidies. According to the SCM agreement, a 'subsidy' is deemed to exist if there is a financial contribution by a government or an income or price support scheme and benefit is thereby conferred ${ }^{10}$ (Art. 1.1). With regard to the term 'financial contribution', ${ }^{11}$ the SCM provides a nonexhaustive list, including grants, loans, and equity infusion, but also to fiscal incentives such as tax credits ${ }^{12}$ and government provision of goods or services other than general infrastructure. ${ }^{13}$ Although the SCM defined the

9 Such as (i) the elimination of industrial, economic and social disadvantages of specific regions; (ii) facilitating the restructuring, under socially acceptable conditions, of certain sectors, especially where this has become necessary by reason of changes in trade and economic policies, including international agreements resulting in lower barriers to trade; (iii) sustaining employment and to encourage retraining and change in employment; (iv) encouraging research and development programmes, especially in the field of high-technology industries; (v) implementing of economic programmes and policies to promote the economic and social development of developing countries; and (vi) redeployment of industry in order to avoid congestion and environmental problems.

10 This means that not all government programs are subsidies under the WTO regime.

11 The provided list of financial contributions applies also when the activities are carried out by a private body on the directions of the government.

12 Whereas exempting an exported product from duties or taxes borne by the like product when destined for domestic consumption, or the remission of such duties or taxes in amounts not in excess of those which have accrued, is not deemed a subsidy.

13 The same was true for the EU until, recently, the Court has turned the tune that not every public infrastructure is outside the scope of aid. See, for example, the Leipzig Halle case (C288/11). 
term 'financial contribution, it fails to explain the equally important term 'benefit', and merely provides some guidelines on how to calculate the benefit (Art. 14). Different from the EU State aid law, in the SCM interpretation, a charge or costs to government or public account is needed for the subsidy to exist (see Fediol v. Commission [1988], paras. 9 \& 11). A further requirement of a subsidy under the SCM is 'specificity', as only specific subsidies are either prohibited or actionable and can trigger countervailing duties. The aim of the specificity requirement is to distinguish measures subject to the subsidy regime from the general market policy applied by the government. In terms of the EU State aid law, specificity is "selectivity", whereas in terms of the SCM, regional aid is not considered specific (Art. 2(2)), while a prohibited subsidy is per se considered specific (Art. 2(3)).

The SCM introduced a traffic light system to divide subsidies into "red (prohibited)", "yellow (actionable) and green (non-actionable)" pursuant to their distorting impact to international competition. The most harmful and thus per se prohibited are the red-light subsidies, such as export subsidies ${ }^{14}$, as well as subsidies contingent on the use of domestic goods over imported ones. Yellow-light or actionable subsidies are not completely prohibited interventions but can be challenged if distorting international trade (Art. 5). Green-light or non-actionable and, therefore, not prohibited are subsidies that have no negative effect on international trade and competition. It is reported in the literature that green-light subsidies ${ }^{15}$ were introduced upon the EU proposal. The aim was to pass on the EU system on exemptions and, with that, to create a legal certainty for EU Member States (Krämer \& Krajewski, 2011; Matsushita et al., 2006) so that any EU-originating legally granted State aid would not trigger countervailing duties under the WTO subsidies regime.

Including all subsidies listed in the illustrative list attached as Annex I of the SCM.

15 Under the green-light subsidies, also a number of experimental new subsidies were introduced, such as R\&D related subsidies, regional development subsidies, and environmental compliance costs related subsidies. They were set to be valid for a term of 5 years, subject to renewal. The experiment ended on 2000 and has not been renewed. 


\section{The origins of EU State aid law and policy}

Almost in parallel to the evolvement of the WTO subsidies regimes, the EU started to develop its own. The Treaty of Paris establishing the European Coal and Steel Community (ECSC) ${ }^{16}$ in 1951 (Vertrag über die Gründung..., 1951) dealt, inter alia, with the issues of balanced trade and fair competition ${ }^{17}$ and strictly banned subsidies. This, however, had little effect as the ECSC member states nonetheless continued granting domestic subsidies (Sykes, 2003).

The Treaty of Rome in 1957 addressed the ultimate goal for the European Community - the economic welfare within the single market (Parret, 2012). As to the specific goals, the establishment "of a system ensuring that competition in the common market is not distorted" (Art. 3(f)) was agreed. For the subsidy regime, there were two options under consideration. Firstly, the rather limited GATT regime and, secondly, the interventionist ECSC rules, which differently from GATT rules, prohibited any subsidies, including domestic subsidies. It is not surprising that the result was a mixture of both, declaring "incompatible with the common market any national aid granted by a Member State or granted by means of State resources, in any manner whatsoever, which distorts or threatens to distort competition by favouring certain enterprises or certain productions shall, to the extent to which it adversely affects trade between Member States", a wording that has remained unchanged until today. In addition to defining the term State aid, although broadly ${ }^{18}$, and prohibiting thereof, the principle of incompatibility was introduced and linked to the list of exceptions provided in the treaty. The aim was to put an end to the Member States' practice of granting aid that effect or object was competition distortion, although it was acknowledged that aids in the general interest as well as aids enabling expanding production do not necessarily need to be prohibited (The Spaak Report, 1956).

16 Between France, West Germany, Italy, Belgium, Luxembourg and the Netherlands. The treaty came into force on 23 July 1952 and expired on 23 July 2002.

17 According to Article 2 of the Treaty, the ECSC "shall have as its task to contribute, in harmony with the general economy of the Member States and through the establishment of a common market as provided in Article 4, to economic expansion, growth of employment and a rising standard of living in the Member States. The Community shall progressively bring about conditions which will of themselves ensure the most rational distribution of production at the highest possible level of productivity, while safeguarding continuity of employment and taking care not to provoke fundamental and persistent disturbances in the economies of Member States".

18 Similarly to Articles 85 and 86 regulating anti-competitive arrangements and abuse of dominancy (now Arts. $101 \& 102$ of the TFEU). 
Even if the substantive State aid rules and the Commission's sole power on executing State aid control within the EU where clearly outlined already in the Treaty of Rome, the development of the EU State aid policy in this period (at least until the early 1980s) was relatively slow, mostly because of the lack of relevant court practice and guidance on what is State aid and how to apply it. Also, in this period, the enforcement by the Commission was weak along with insufficient cooperation vis-à-vie Member States as well as the Commission (López, 2015). It was not before the 1980s when the Commission started to apply stricter State aid control ${ }^{19}$ and to develop the State aid policy though different soft-law instruments such as frameworks and guidelines. ${ }^{20}$ For example, in the Second Report on Competition Policy (1973), the Commission refers to the need to distinguish between aid given to agencies engaged in research on a non-profit-making basis (such as universities) and to firms, referring that only the latter should be captured by Article 107(1). ${ }^{21}$ This can be seen as the Commission making first steps with regard to measures related to Research and Development and Innovation aid (R\&D\&I). Around this time, the Commission also clearly stated that the State aid policy needs to be created by the Community and not on the national level. The Tenth Report on Competition Policy Commission refers to the famous Philip Morris case (Philip Morris Holland BV v. Commission of the European Communities [1980]), summing up

that the considerable discretionary power provided to the Commission by Article 107(3) is clear along with the standpoint that state aids are in principle incompatible with the common market. Also, that the discretionary power of the Commission should only be exercised when the aids proposed by Member States contribute to the achievement of the Community objectives and interest set out in Article 107(2). The national interest of a Member State or the benefits obtained by the recipient of aid in contributing to the national interest do not by themselves justify the positive exercise of the Commission's discretionary powers. (Tenth Report, 1980, p. 216)

19 Today under Article 108(2) of the TFEU, but previously under Article 93 (2) of the Treaty of Rome or Article 88 (2) of the Treaty of European Communities, respectively.

20 It has to be noted that soft-law instruments are binding on the Commission only and are aimed at creating greater legal certainty for the aid providers and receivers.

21 The Commission refers to Decision 72/261 in which the latter considered from a State aid point of view a low interest credits for the import of scientific instruments and sophisticated technology apparatus to undertakings as well as to agencies of public interest. 
The Treaty of Maastricht ${ }^{22}$ from 1992 is not only marking the start of an era in the process of even closer cooperation and approximation of economic policies and legal systems of the Member States, but it also launched even tighter State aid control by the Commission. Around this time, the State aid rules got more integrated with other areas of competition law. It seems that this time also indicates a turning point where the State aid rules are no longer seen as the rules preventing distortions between the Member States but rather preserving competition between competitors (López, 2015), so protecting the competitors which eventually developed into the concept of 'level playing field'. For most of the last few decades, the Commission has been clearly on the position that subsidies contribute little to lasting economic welfare; on the contrary, they lead to unfair competition between undertakings, to market distortions and an inefficient allocation of resources, additionally putting the achievements of internal market at risk as they also tend to create or increase barriers to trade. For the Commission, the only benefit of state aid is the remedy of market imperfections (market failure), provided granting of aid takes place under precise conditions and strict Commission control. As to the market failure,${ }^{23}$ it is neither expressis verbis addressed in the treaties or the relevant secondary legislation, still it is seen

22 The importance of the Treaty of Maastricht lays in establishing the single currency, the euro, and expanding the cooperation between the member state in areas such as common foreign and security policy, closer cooperation between police and the judiciary in criminal matters, as well as creating the European citizenship.

23 The Commission's hard- and soft-law instruments are either silent or rather modest in defining the term. Only in its State Aid Action Plan from 2005, the Commission elaborated the concept thoroughly and, according to this, a "market failure" is consequently a situation where the market does not lead to an economically efficient outcome. Market failures have different origins, and notably:

- Externalities exist where actors do not take full account of the consequences of their actions on other actors in society. Market players may not have to pay for the full social cost of their actions (negative externalities), as in the case of pollution through industrial activity. Market players may also be unable to reap the full benefits of their actions (positive externalities), as in the fields of research and innovation.

- Public goods are goods which are beneficial for the society but which are not normally provided by the market given that it is difficult or impossible to exclude anyone from using the goods (and hence making them pay for the goods). This can be the case of national defense and some types of public broadcasting.

- Imperfect information may lead to transaction costs, agency costs, moral hazard, or antiselection, which in turn leads to inefficient market outcomes. A well-known example of imperfect information can be found in the financial market, where start-up firms usually face problems in finding adequate funding.

- Coordination problems. Markets may also not function efficiently when there is a coordination problem between market actors. Coordination problems may exist, for example, in the field of standard setting, in transport infrastructures, or in the area of innovation.

- Market power. Another reason why the market may not lead to an efficient outcome is the existence of market power, for instance, in a situation of monopoly. 
as a cornerstone of compatibility analysis under Articles 107(2) and (3) of the TFEU and, as such, are dealt with in the Commission soft law, such as, for example, the R\&D\&I framework (Communication 2014/C 198/01), rescuing and restructuring guidelines (Communication 2014/C 249/01), guidelines for environmental protection (Communication 2014/C 200/01), or regional aid guidelines (Communication 2013/C 209/01). For example, the access of SMEs, which are considered an important part of EU economy, to capital markets is being considered limited, there exists market imperfection, and thus, for the Commission, an aid measure program that aims at helping the SMEs to compete creates a 'level playing field'. The same concept is provided by the Commission with regard to permitting state interference under regional aid, R\&D\&I, environmental programs, and so on. This indicates that even though the EU State aid needs to be interpreted and implemented in accordance with the aim and specific goals of the treaties, they cannot be applied in a vacuum, but in accordance with the relevant realities of economic, social and political environment within the EU but also beyond.

A further relevant milestone happened soon after entering into force of the Treaty of Amsterdam, which itself provided no changes with regard to State aid rules, but after which the Commission established its view on the financing of services of general economic interest (SGEI) and launched, in 2005, an ambiguous State aid policy reform called the State Aid Action Plan (SAAP) with a leading motive "less and better targeted aid" and an ambiguous plan to revise all rules and regulations. SAAP is described as a turning point of the EU State aid policy. It aimed to bring State aid closer to other areas of competition policy and notably start using State aid as an instrument to support EU policy objectives in a way that it is no longer seen as a legal control mechanism keeping the Member States from intervening into domestic economy, but to see the State aid regime as a policy tool supporting and achieving common EU goals and objectives (Kleiner, 2011) in such fields as R\&D\&I, employment, training, environment (Kleiner, 2008). SAAP called for better cooperation, higher predictability, more effective procedures and better enforcement. It also introduced the "economy-based approach" ${ }^{24}$ in the field of compatibility instead of a strict and formalistic application of legal norms applied so far. The balancing test applied today in the examination of the compatibility of State aid is the direct influence and execution of this effect-based approach. Among others, the Commission introduced the principle that aid measures should be directed towards sectors rather than individual companies. SAAP was greatly

24 An application of economy-based approach can be seen in Commission's operations during the recent financial crisis where the latter invoked Article 107(3)b) when assessing aids granted to banks. 
motivated by the fact that the concept of aid on the EU level was still unclear, and severe procedural shortcomings existed (Kleiner, 2011) and completely reoriented the EU State aid policy. During the execution of SAAP initiative and in the light of the financial crisis, the Treaty of Lisbon introduced, in 2009, major changes not only to the set of treaties ${ }^{25}$, institutions ${ }^{26}$ and legislative processe ${ }^{27}$, but reformed appreciably, according to some commentators even alarmingly, the objectives regarding the undistorted competition ${ }^{28}$. It did not, however, change the primary State aid law until 2012, when the next reform initiative Standing for State aid Modernization (SAM) was launched. SAM's main aim is to attach State aid policy to the Europe 2020 strategy, namely (i) to foster sustainable, smart and inclusive growth in a competitive internal market; (ii) to focus the Commission's ex ante scrutiny on cases with the biggest impact on the internal market whilst strengthening the Member States' cooperation in State aid enforcement; (iii) to streamline the rules and provide for faster decisions (Commission Communication COM(2010) 2020 final).

Similarly to SAAP, SAM addressed the compatibility analysis, established tools and criteria for growth-enchanting good aid. ${ }^{29}$ As a result of the SAM initiative, the Commission adopted and revised a number of softlaw instruments as well as secondary EU law, including the notice on the notion of State aid (Commission Notice 2016/C 262/01), R\&D framework (Communication 2014/C 198/01), guidelines on regional State aid from 2014 -2020 (Communication 2013/C 209/01) and general block exemption (GBER) (Commission Regulation (EU) 651/2014).

In the light of the recent initiative on green and digital transformation, the Commission recently launched a new review of the State aid law and

25 The foundation of the EU is formed of two treaties: the Treaty on European Union (TEU) and the Treaty on the Functioning of the European Union (TFEU).

26 For example, establishing the role of permanent President of the European Council or the election process for the president of the Commission.

${ }_{27}$ The treaty introduced a new qualified majority voting system, the aim of which was to balance the small and large Member States. It also established areas that remain subject to unanimity voting (such as tax, citizens' rights, security and defense policies, etc.).

28 Namely, the goal to ensure a system that competition in the internal market is not distorted was abolished in the main text of the treaties and included into the Protocol on the Internal Market and Competition, where it reads as follows: "Contracting Parties considering that the internal market as set out in Article 3 of the Treaty on European Union includes a system ensuring that competition is not distorted, HAVE AGREED that: To this end, the Union shall, if necessary, take action under the provisions of the Treaties, including under Article 352 of the Treaty on the Functioning of the European Union. This protocol shall be annexed to the Treaty on European Union and to the Treaty on the Functioning of the European Union."

29 As opposed to bad aid, i.e., per se prohibited aid. 
policy. Unfortunately, not much is yet known on the activities conducted, as the Commission's official webpage only provides a table of activities along with the estimated deadlines, it is however envisaged that almost all Commission State aid related soft-law instruments are currently under review, including R\&D framework, GBER and Regional Aid Guidelines ${ }^{30}$. The recent Commission's action could be understood, however, that today's EU State aid rules are, in fact, not sufficiently supporting the EU aims when facing the trends in economy on the global but also the internal level.

\section{The origins and development of Estonian State aid law}

Prior to joining the WTO or the EU, Estonia had neither subsidy law nor any policy thereof. ${ }^{31}$ The first legal act regulating state interference was the Competition Act from 1998. Pursuant to the explanatory memorandum of the 1998 law, the drafters considered that an appropriate State aid policy gives the government the opportunity to encourage businesses to make investments significant for the public and society, especially as the drafters held Estonia to be the Article 107(3)(a) region. Considering this and Estonia's aspirations to join the EU, it was proposed to take over and apply in Estonia the EU State aid principles (Explanatory memorandum, 1998). According to the wording of the 1998 law, State aid was a

financial advantage granted by a state, city or rural municipality or through their means which distorts or threatens to distort competition by favoring certain undertakings or the production or sale of goods, including financial assistance, deferred payment of debts, cancellation of debt or provision of loans on terms significantly more favorable than applied to other traders (Competition Act, 1998, para. 19(1)).

Law provided an exhaustive list of permissive State aid, which also included State aid for R\&D, for environmental protection, or aid to remedy a serious disturbance in the economy. According to the 1998 Competition Act, national State aid law also applied to domestic aid, that is, the aid that was outside

30 See the timeline at https://ec.europa.eu/competition/state_aid/legislation/timeline_table_ SA_final.pdf

31 Estonia's very first law on competition, adopted on 16 June 1993, dealt mainly with issues related to unfair competition and anticompetitive conduct between undertakings. For the text of the legal act together with the explanatory memorandum, see Explanatory memorandum, 1993. 
the competences of the Commission.

The next major Estonian State aid law reform took place in 2001. According to the available explanatory memorandum, changes made to the state aid regime aimed better regulation and increasing implementation capacity (Explanatory memorandum, 2001). Although the Competition Act from 2001 maintained the concept of State aid provided in the previous, 1998 law, it nevertheless amended the concept by adding that only State aid compatible with the common interest can be granted. A new list of aid considered compatible with common interest was added, substituting the previous one, whereas the new list reflected the compatibility principles set out in Article 107(3) of the TFEU. So, specific references to R\&D aid but also to environmental aid and aid to remedy serious economy disturbances were all abolished. As a novelty, it was established that export aid $^{32}$ and aid to replace import ${ }^{33}$ is not compatible with the common interest; however, an aid granted to an undertaking for the purpose of participating in trade fairs and for studies or consultancy services necessary for the launch of a new or existing product on a new market was not deemed to be export aid. Also, export guarantees and credits were considered compatible with the general interest. In 2004, national rules on export and aid to replace import were abolished with the explanation that export aid is regulated by the legislation of the EU and Estonia has no right to interpret them with national acts.

In 2004, after Estonia joined the EU, another review was launched with the main purpose of bringing the national State aid regime into line with the EU State aid law. According to the explanatory memorandum (Explanatory memorandum, 2004) of the relevant draft law, since upon Estonia's accession to the EU, the EU legislation in force in the field of State aid applies directly in Estonia and there is no need to define State aid on the national level and instead refer to the relevant EU provisions.

In 2007, another review took place with the aim to enter changes that have taken place on the EU level also in the Estonian State aid law. In 2007, the national law was amended with the condition that State aid can be granted only to remedy a market failure for a specified period and to the extent necessary to achieve the objective referred to in Articles 107(2) and (3) of the TFEU. In the explanatory memorandum (Explanatory memorandum, 2007),

\footnotetext{
32 Export aid covered aid that directly linked to the quantities of goods exported, to the establishment and operation of a distribution network or to other current expenditure linked to the export activity.

33 Aid to replace imports covered aid granted to an undertaking for the use of domestic over imported goods.
} 
the lawmakers quote the EU SAAP initiative (referred to above), addressing the concept of market failure, arguing that the concept does not need to be opened or clarified, as it is a general economic term, it occurs when a selfregulatory market does not deliver a cost-effective outcome. It is stressed, however, in the explanatory memorandum that analysing the existence and magnitude of a market failure will help to better assess whether State aid is justified, appropriate and proportionate.

In 2012, the national State aid law was reviewed and amended again. According to the lawmakers, the rules needed to be brought in line with the EU State aid regime, also domestic implementation was an issue. Among other, for the purposes of this article, less important changes, the national State aid law was amended with the condition that aid granted must have an incentive effect. In the explanatory memorandum (Explanatory memorandum, 2012), the lawmakers argued that it is not possible to open or define the concept of incentive effect in Estonian national law, because the Commission's relevant legislation does not open or define it—-the Commission's legislation merely provides the conditions under which State aid is considered to have an incentive effect. It seems that national lawmakers, without understanding the concept of incentive effect, and merely referring to the fact that the Commission's legislation and opinions refer to the incentive effect, adopted the approach that, before granting any aid, the aid grantor must ensure that aid has an incentive effect on the recipient. ${ }^{34}$

Based on the above, the currently valid Estonian State aid regime mirrors to a large extent the EU State aid law.

Additionally to what has already been addressed to above, the national State aid regime excludes areas such as the transport sector and aid related to the production, processing or marketing of agricultural or fishery products or forestry from the application of national State aid regime (para. 30(3)). It also specifies who shall be understood as the grantor of State aid, namely the local government, or other body ${ }^{35}$, which directly or indirectly uses the resources of the state or local government for granting State aid (para. $30^{1}(1)$ ). If the aid grantor cannot be determined, it shall be appointed by the Government of the Republic (para. $30^{1}\left(1^{1}\right)$ ). It is the obligation of the

${ }_{34}$ A condition that resulted in many legal disputes on national but also EU level. In the ECJ case C-349/17 (Eesti Pagar AS v. Ettevõtluse Arendamise Sihtasutus and Majandus- ja Kommunikatsiooniministeerium [2019]), European Court of Justice provided further clarifications on how the concept of incentive effect needs to be understood and applied.

35 Including a foundation, non-profit association, legal person in public law or public undertaking. 
aid grantor to ensure the transparency and efficiency of the aid as well as to inspect the purposefulness of use of aid (para. $30^{1}(2)$ ). Also, the grantor of aid is prohibited from granting aid before the Commission has made a permitting decision allowing the aid, except if the aid is covered by group exemptions (para. $30^{1}\left(2^{1}\right)$ ). Estonian national State aid law regulates de minimis aid (para. 33), referring mainly to relevant Commission regulations. Law also regulates the submission of the notice on State aid to the Commission (para. $34^{1}$ ), application of group exemptions (para. $34^{2}$ ), establishing and maintaining the register of de minimis aid (para. 492), reporting on State aid to the Commission (para. 49), co-operation with Commission as regards supervision and on-site inspections (para. 491), as well as recovery of unlawful state aid or misused aid (para. 42). Although relevant, these issues are not considered in detail, as they fall outside of the scope of this article.

\section{Discussion}

As can be seen from the above, Estonia has taken over the body of EU State aid law by regulating that State aid is any aid laid down in Article 107(1) of the TFEU. It is not entirely clear, however, if and how to apply Article 107(1) in case of domestic aid, i.e., situations where all four State aid criteria $^{36}$ set out in Article 107(1) are not met; however, that would constitute transferring state resources along with conferring an economic advantage. According to Article 3(b) of the TFEU, the "Union has exclusive competence in establishing of the competition rules necessary for the functioning of the internal market", implying that competition rules not affecting the internal market fall outside the EU's exclusive competence.

As indicated above, Estonian law is silent on the term 'market failure' and does not refer to any other legal act substantiating the term. ${ }^{37}$ On the EU level, the term 'market failure' is also not defined or addressed to in the TFEU or relevant secondary legislation, yet it is seen as a cornerstone of compatibility analyses under Articles 107(2) and (3) of the TFEU and, as

\footnotetext{
36 The general definition set out in Article 107(1) of the TFEU requires that the (i) aid measure is financed through state resources and be imputable to the state; (ii) aid is conferring an economic advantage on its recipient; (iii) advantage is selective; and (iv) distorts or threatens to distort competition and affects the trade between Member States.

37 In Regulation no. 38 (2017) enforced by the Minister of Enterprise and Information Technology in Estonia on 13 July 2017 for supporting the development of local government housing, local government housing market failure is considered to exist if the demand for rental premises exceeds the supply.
} 
such, is dealt in the Commission soft law, such as, for example, the R\&D\&I framework (Communication 2014/C 198/01), rescuing and restructuring guidelines (Communication 2014/C 249/01), guidelines for environmental protection (Communication 2014/C 200/01) or regional aid guidelines (Communication 2013/C 209/01). EU soft law is generally not binding on the Member States, thus the definition of market failure provided in the referred soft-law instruments cannot be considered legally binding. This means, on the one hand, that the Member States may use the term in the same context with the Commission, but they do not need to. This, however, can lead to a situation where the Member States understand and apply the term 'market failure' differently. A situation considered a market failure in Estonia is not considered as such in some other Member State. For the sake of clarity, especially for the benefit of aid receivers, Estonian lawmakers could and should have clearly indicated what is a market failure. Also, considering that Estonian national law allows aid only for the elimination of market failures during a specified term and to the extent necessary to achieve the objective specified in Articles 107(2) and (3) of the TFEU. Does this mean that no aid can be granted on the domestic level if markets are working fine even if the Commission has allowed the aid?

A similar problem on the domestic level emerges with the concept of incentive effect, which on the EU level has its origins in the SAM initiative and is aimed at facilitating sustainable, smart and inclusive growth and has resulted in adopting the so-called general block exemption (GBER). ${ }^{38}$ Aid is deemed to have an incentive effect if the beneficiary has submitted a written application for the aid to the Member State concerned before work on the project or activity starts along with information requested in Article 6 of GBER. Different from the definition of 'market failure', incentive effect has been addressed to in the regulation, meaning that under Article 288 of the TFEU it is binding and directly applicable. The issue with incentive effect principle, however, is that in many cases, the work on the project has already started before the issue on public support becomes relevant. Thus, does this mean on the domestic level that any support to such projects is banned and excluded, even if the Commission approves granting the aid?

No doubt, Estonia has to comply with both the WTO and EU State aid regimes; however, it is not clear if the supranational policies can and should also be applied on aid that is only subject to national law. Neither is it clear or understandable why the Estonian national State aid policy has adopted

38 Regulation (EC) No. 800/2008 which was repealed and replaced in 2014 with the Regulation (EU) No. 651/2014 applicable until 31.12.2020. 
the approach that state intervention is allowed in case of a market failure only and to interfere, there must be an incentive effect. There are several Member States, the State aid policy of which does not address market failure ${ }^{39}$ and correction ${ }^{40}$ but redistribution ${ }^{41}$. Accepting state intervention in case of market failures or redistribution makes an appreciable difference, whereas the question on allocative efficiency or redistribution in case of market failure seems less of an economic or legal question and more of a political issue (Blauberger, 2009). Allowing State aid only if an incentive effect is present, as Estonian lawmakers have stated in law, limits substantially the flexibility of the public sector to provide the private sector public support as the incentive effect is not necessarily always present.

The above strongly indicates that Estonian national State aid policies are predetermined at the European level, more precisely by the Commission. This poses the question whether Estonia has any national State aid policy? A national State aid policy, however, is inevitable when aiming to promote Estonian national economy. Although the Commission is constantly reforming the State aid soft-law instruments to adjust them to the global trends and the EU's position on the global market and in competition with other states and regions, these can never address the needs of all Member States, at least not on an equal footing. The question is whether there can be a conflict between the national State aid policy and its supranational control, executed by the Commission or the WTO. The answer should be affirmative, as the national State aid law is seeking for domestic objectives, while the supranational State aid regime has clearly international dimensions. For example, Estonia has, within the last decades, successfully created a digital society, where most public services are available only or also in digital form. Although the Estonian public sector is highly digitalized, the private sector seems to be lagging far behind. To fund public sector innovation, the state neither needs to respect the concept of incentive effect nor eliminates the market failure. On the other hand, using public funding for the digitalization of the private sector or for emerging, developing and use of new technologies, such as Artificial Intelligence (AI) or the Internet of Things (IoT), in the private sector is subject to State aid regimes and, therefore, very much limited due to applicable supranational State aid but even more domestic State aid rules. Both concepts-that is, market failure and incentive effectare also essential when we speak of supporting private sector innovation. Although financing innovation is the key function of the banking system and

\footnotetext{
For example, Estonia and United Kingdom.

For example, Sweden and Denmark.

${ }^{41}$ For example, Germany and Poland.
} 
the main capitalistic method of effecting economic progress, as indicated almost 100 years ago by Schumpeter, financial institutions are very careful in financing novel products or services. This justly raises the question of using public capital. In the US, the State has played an important role in fostering innovation (Mazzucato, 2015). The US government has reportedly not only fixed market failures but has also effectively changed the way markets work or even created new ones, thus they convincingly advocate that public finances have been effectively and successfully used for innovation (Mazzucato, 2015). No doubt, public funding may incentivize innovation and the emerging new technologies that would not otherwise take place, for example in the case of market failure, but do we really need to limit the private sector's technical advance with rules that market failure and incentive effect are a prerequisite for state intervention?

Furthermore, in the EU, R\&D State aid related business risk, caused by imperfect and asymmetric information inherent to R\&D projects, is not even considered a market failure in itself (as provided in Section 49 of the R\&D\&I Framework), posing the question whether R\&D can be supported with public funds based on national law, if market failure is not provided? On the other hand, aid that can bring a material improvement that the market cannot deliver itself, for example by remedying market failure or addressing an equity or cohesion concern, can be considered compatible by the Commission (Section 36(b) of the R\&D\&I Framework). Therefore for the compatibility, the presence of market failure is not a prerequisite but an alternative ground. The same is provided in the regional aid guideline (Section 26(b) and rescuing and restructuring guidelines (Section 38(b)). In the guidelines for environmental protection, the Commission points out that a "mere existence of market failures is not sufficient to justify state intervention" (Section 36), whereas a remedy of a well-defined market failure is a clear prerequisite (Section 27(b)) for compatibility for aid. Based on the above and even though the concept on market failure seems to be a cornerstone of compatibility analysis under Articles 107(2) and (3) of the TFEU, executed by the Commission, there is in fact no legal reasons why Estonian State aid policy should allow the state to intervene only if market failure exists. 


\section{Conclusion}

As a small country and a non-founding member of the WTO or the EU, Estonia has neither participated in creating their subsidies rules nor has substantially influenced their application. Both rules, however, affect Estonian economy and policymaking aiming, for example, at increasing employment, raising wages, fostering innovation, promoting export, or to address market failures. Legal constraints and the obligation of the Member States to obtain the Commission's approval before implementing measures largely means that the Member States' State aid policies are shaped, at least indirectly, by the EU (Kleiner, 2011). Even though under the treaties, the Commission is expressis verbis allocated only with the competence of controlling national State aid, the policies adopted in the form of the Commission's soft-law instruments, such as frameworks, guidelines, but also the practice of European courts, guide the Member States on the compatibility and, doing so, instruct them on how they should design and prescribe their own State aid policies. This development, in which the Commission is granted more and more power to influence the economic policy of the Member States, has evoked over time. On the one hand, the comprehensive State aid rules that apply uniformly to all Member States, imposing a general ban on State aid and allowing exceptions only with the Commission's agreement, are effective since they are facilitating greater economic integration between the Member States. And if economies are doing fine, it can be assumed that greater general economic welfare is created. On the other hand, however, it reduces the independence and self-decision making of the Member States (Kleiner, 2011) and bears the risk of the approach of 'one size fits all', as it usually does not. Therefore, even a small WTO and EU Member State, such as Estonia, should definitely have its own State aid policy, which is in compliance with the applicable supranational regimes while carrying primarily Estonia's national interests. The currently valid national rules are, unfortunately, not a good example of that.

Evelin Pärn-Lee is a junior researcher and a PhD student at the Tallinn University of Technology (TalTech). Her research is related to the interface of EU competition law, intellectual property law, innovation and ICT in general, as the private and public sector's endeavours to innovate pose different challenges for competition regimes. In her doctoral thesis, she explores whether the EU State aid framework 
and implementation thereof, when fostering innovation, adequately considers the ultimate aim of the EU's competition law and policy, which protects competition in order to maintain a level playing field in the Digital Single Market. Apart from academic work, she has over 20 years of international consultancy experience as an attorney at law.

\section{Bibliography}

Almunia, J. (2014), 'Statement on new state aid rules for R\&D and innovation and on the extended notification exemptions of state aid,' Speech at press conference, European Commission, Brussels, 21 May 2014. Retrieved from http://europa.eu/rapid/press-release_SPEECH-14-402_en.htm [accessed Mar 2020]

Blauberger, M. (2009), 'Of good and bad subsidies: European State aid control through soft and hard law,' West European Politics, vol. 32, no. 4, pp. 719-737. https://doi.org/10.1080/01402380902945300

Boundanella, P. \& Musa, M. (1979), 'The Prince,' in The Portable Machiavelli, New York: Penguin Book, pp. 77-166.

Brogan, O. (1936), 'Trade between the Roman Empire and the free German,' The Journal of Roman Studies, vol. 26, no. 2, pp. 195-222. https://doi. org/10.2307/296866

Buendía Sierra, J. L. \& Smulders, B. (2008), 'The limited role of the "refined economic approach" in achieving the objectives of state aid control: time for some realism,' in V. Di Bucci, J. L. Buendía Sierra \& B. Smulders (eds.) EC State Aid Law - Le Droit des Aides d'Etat dans le CE, Liber Amicorum Francisco Santaolalla Gadea, Alphen aan den Rijn: Kluwer Law International, p. 18.

Buttigieg, E. (2009), Competition Law: Safeguarding the Consumer Interest. A Comparative Analysis of US Antitrust Law and EC Competition Law, Alphen aan den Rijn: Kluwer Law International.

Commission Communication 'Europe 2020 - A strategy for Smart, Sustainable and Inclusive Growth', $\operatorname{COM(2010)} 2020$ final, 3.3.2010.

Commission Notice on the notion of State aid as referred to in Article 107(1) of the Treaty on the Functioning of the European Union, 2016/C 262/01, OJ C 262, 19.7.2016.

Commission Regulation (EU) no. 651/2014 of 17 June 2014 declaring certain categories of aid compatible with the internal market in application of Articles 107 and 108 of the Treaty, OJ L 187/1, 7.6.2014. 
Communication from the Commission, Framework for State aid for research and development and innovation, 2014/C 198/01, OJ C 198, 27.6.2014 Communication from the Commission, Guidelines on regional State aid for 2014-2020, 2013/C 209/01, OJ C 209, 23.7.2013.

Communication from the Commission, Guidelines on State aid for environmental protection and energy 2014-2020, 2014/C 200/01, OJ C 200, 28.6.2014.

Communication from the Commission, Guidelines on State aid for rescuing and restructuring non-financial undertakings in difficulty, 2014/C 249/01, OJ C 249, 31.7.2014.

Competition Act, RT I 1998, 30, 410. Retrieved from https://www.riigiteataja. ee/akt/74948 [accessed Mar 2020]

Competition Act, RT I 2001, 56, 332. Retrieved from https://www. riigiteataja. ee/akt/22479 [accessed Mar 2020]

Didier, P. (1999), WTO Trade Instruments in the EU Law. Commercial Policy Instruments: Dumping, Subsidies, Safeguards, Public Procurement, London: Cameron May.

EEC Seed Crushers' and Oil Processors' Federation (Fediol) v. Commission of the European Communities [1988], CJEU 2176/84, C-187/85, ECLI:EU:C:1988:399.

Eesti Pagar AS v. Ettevõtluse Arendamise Sihtasutus and Majandusja Kommunikatsiooniministeerium [2019], CJEU C-349/17, ECLI:EU:C:2019:172.

Explanatory memorandum (1998), Explanatory memorandum to the 1998 Competition Act. Retrieved from https://www.riigikogu.ee/ tegevus/eelnoud/eelnou/eaae79f4-1179-36a2-a150-cb711823baf6/ Konkurentsiseadus [accessed Mar 2020]

Explanatory memorandum (2001), Explanatory memorandum to the 2001 Competition Act. Retrieved from https://www.riigikogu.ee/ tegevus/eelnoud/eelnou/eeb64fc8-968c-3ca5-bd71-1cd6446a126f/ Konkurentsiseadus [accessed Mar 2020]

Explanatory memorandum (2004), Explanatory memorandum to the 2004 amendments. Retrieved from https://www.riigikogu.ee/ tegevus/eelnoud/eelnou/98b06494-dec1-37ba-bfe1-036ac729f4e8/ Konkurentsiseaduse\%20muutmise\%20seadus [accessed Mar 2020]

Explanatory memorandum (2007), Explanatory memorandum to the 2007 amendments. Retrieved from https://www.riigikogu.ee/ tegevus/eelnoud/eelnou/4f2d2f97-a9b6-ec34-d725-b4ff56fbd596/ Konkurentsiseaduse\%20muutmise\%20seadus [accessed Mar 2020] 
Explanatory memorandum (2012), Explanatory memorandum to the 2012 amendments. Retrieved from https://www.riigikogu.ee/ tegevus/eelnoud/eelnou/267e5cc1-672d-4680-b955-64521279b1c2/ Konkurentsiseaduse\%20muutmise\%20seadus [accessed Mar 2020]

Friederiszick, H. W.; Röller, L.-H. \& Verouden, V. (2006), 'European state aid control: an economic framework,' in P. Buccirossi (ed.) Handbook of Antitrust Economics, Chapter: European State Aid Control: An Economic Framework, Cambridge, MA: MIT Press, pp. 625-669.

Gordon, C. D. (1949), 'Subsidies in Roman imperial defence,' Phoenix, vol. 3, no. 2, pp. 60-69.

Hoekman, B. M. \& Kostecki, M. M. (2006), The Political Economy of the World Trading System: The WTO and Beyond, 2nd ed., Oxford: Oxford University Press.

Hofmann, H. C. H. \& Micheau, C. (2016), State Aid Law of the European Union, Oxford: Oxford University Press.

Kerikmäe, T. \& Pärn-Lee, E. (2018), 'Digitalisation and automatisation as challenges for changing the European Union,' in N. Šišková (ed.) European Union - What is Next? A Legal Analysis and the Political Visions on the Future of the Union, Alphen aan den Rijn: Wolters Kluwer, pp. 296-313.

Kerikmäe, T. \& Pärn-Lee, E. (2020, forthcoming), Legal Dilemmas of Estonian Artificial Intelligence Strategy: In Between of e-Society and Global Race.

Kleiner, T. (2011), 'Modernization of State aid policy,' in E. Szyszczak (ed.) Research Handbook on European State Aid Law, Cheltenham: Edward Elgar, pp. 1-27.

Kleiner, T. (2008), 'The State aid Action Plan,' in W. Mederer et al. (eds.) EU Competition Law: State Aid, vol. IV, Deventer: Claeys \& Casteels.

Krämer, R. \& Krajewski, M. (2011), 'State aid (subsidies) in international trade law,' in E. Szyszczak (ed.) Research Handbook on European State Aid Law, Cheltenham: Edward Elgar, pp. 404-424.

López, J. J. P. (2015), The Concept of State Aid under EU Law: From Internal Market to Competition and Beyond, Oxford: Oxford University Press.

Matsushita, M.; Schoenbaum, T. J. \& Mavroidis, P. C. (2006), The World Trade Organization - Law, Practice, and Policy, 2nd ed., Oxford: Oxford University Press.

Mazzucato, M. (2015), The Enterpreneurial State: Debunking Public vs Private Sector Myths, New York \& London: Anthem Press.

Mitteldeutsche Flughafen AG and Flughafen Leipzig-Halle GmbH v. European Commission [2012], CJEU, C-288/11 P, ECLI:EU:C:2012:821. 
Parret, L. (2012), 'The multiple personalities of EU competition law: time for a comprehensive debate on its objectives,' in D. Zimmer (ed.) The Goals of Competition Law, Cheltenham: Edward Elgar, pp. 61-84.

Philip Morris Holland BV v. Commission of the European Communities [1980], CJEU, C-730/79, ECLI:EU:C:1980:209.

Regulation no. 38 (2017), Minister of Enterprise and Information Technology in Estonia, 13.7.2017.

Second Report on Competition Policy (1972), Luxembourg: Office for Official Publications of the European Communities. Retrieved from http:// ec.europa.eu/competition/publications/annual_report/ar_1972_en.pdf [accessed Mar 2020]

Sykes, A. (2003), The Economics of WTO Rules on Subsidies and Countervailing Measures, U Chicago Law \& Economics, Olin Working Paper no. 186. https://doi.org/10.2139/ssrn.415780

Tenth Report on Competition Policy (1981), Luxembourg: Office for Official Publications of the European Communities. Retrieved from http:// ec.europa.eu/competition/publications/annual_report/ar_1980_en.pdf [accessed Mar 2020]

The Spaak Report (1956), Report of the Heads of Delegation to the Ministers of Foreign Affairs, of 21.4.1956.

Vertrag über die Gründung der Europäischen Gemeinschaft für Kohle und Stahl (1951), 11951K/TXT. Retrieved from https://eur-lex.europa.eu/legalcontent/DE/TXT/PDF/?uri=CELEX:11951K/TXT\&from=EN [accessed Mar 2020] 